\title{
İlk Trimester Tarama Test Biyobelirteçlerinin Gestasyonel Diyabetes Mellitus İle İliş̧kisi
}

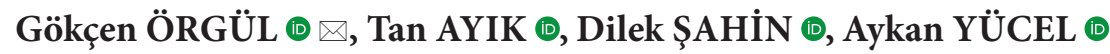

Sağlık Bilimleri Üniversitesi, Etlik Zübeyde Hanım Kadın Hastalıkları Eğitim ve Araştırma Hastanesi, Perinatoloji Kliniği, Ankara, Türkiye

Bu makaleye yapılacak atıf: Örgül G, Ayık T, Şahin D, Yücel A. İlk Trimester Tarama Test Biyobelirteçlerinin Gestasyonel Diyabetes Mellitus ile İlişkisi. Türk Diyab Obez 2020;1: 41-45.

\section{ÖZET}

Amaç: İlk trimester Down Sendromu tarama testi olarak biyokimyasal belirteçler olan gebelik ile ilişkili plazma protein A (PAPP-A) ve human koriyonik gonadotropin serbest beta alt birimi ( $\beta$-hCG) kullanılmaktadır. Bu çalışmada gebeliğin ilk üç ayında yapılan kombine test sonuçlarının gestasyonel diabetes mellitus (GDM) ile ilişkisi araştırılmıştır.

Gereç ve Yöntemler: Çalışma grubunu GDM tanısı alan ve doğumu 1 Ağustos 2018 ile 31 Ekim 2018 arasında hastanemizde gerçekleşen 95 hasta oluşturmaktaydı. Kontrol grubu için hastanemizde termde doğum yapan, ek hastalığı olmayan, gebelik komplikasyonu saptanmayan ve kombine test sonuçlarına ulaşılabilen 100 hasta rastgele seçilmiştir. Gruplardaki hastaların ilk trimester serum $\beta$-hCG ve PAPP-A düzeyleri karşılaştırılmıştır.

Bulgular: PAPP-A düzeyi ve MoM değeri ile $\beta$-hCG düzeyi ve MoM değeri GDM grubunda daha düşük saptanmıştır (sırasıyla, $\mathrm{p}=0,013$, $\mathrm{p}=0,081, \mathrm{p}=0,001$ ve $\mathrm{p}=0,007$ ). En ideal kesme değeri PAPP-A için 1,715 ng/mL (duyarlılık \%61 ve özgüllük \%22) ve PAPP-A MoM için 0,905 (duyarlılık \%51,6 ve özgüllük \%39) olarak bulundu. En ideal kesme değeri B-hCG için 25,75 mIU/mL (duyarlılık \%56,8 ve özgüllük \%30) ve $\beta$-hCG MoM için 0,745 (duyarlılık \%57,9 ve özgüllük \%28) olarak bulundu.

Sonuç: PAPP-A ve $\beta$-hCG düzeyleri GDM gelişenlerde sağlıklı gebelere kıyasla daha düşüktür. Ancak hem PAPP-A hem de $\beta$-hCG için bulunan ideal kesme değerlerde yalancı pozitiflik oranları oldukça yüksektir.

Anahtar Sözcükler: Diyabet, Gebelik, Gebelik ilişkili plazma proteini A, Koryonik gonadotropin, Beta altünitesi, Insan

\section{Relationship Between First Trimester Screening Test Biomarkers and Gestational Diabetes Mellitus}

\begin{abstract}
Aim: Pregnancy-related plasma protein A (PAPP-A) and human chorionic gonadotropin free beta subunit ( $\beta$-hCG) are used as biochemical markers in first trimester Down Syndrome screening. The relationship between gestational diabetes mellitus (GDM) and combined test results was investigated in this study.

Material and Methods: The study group consisted of 95 patients who were diagnosed as GDM and gave birth at our hospital between 1 August 2018 and 31 October 2018. The control group consisted of 100 patients who were delivered at term in our hospital, had no additional disease or pregnancy complications with combined test results. First trimester serum $\beta$-hCG and PAPP-A levels of the patients were compared.

Results: PAPP-A level and MoM value and $\beta$-hCG level and MoM value were lower in GDM group. (p value 0.013; $0.081 ; 0.001$ and 0.007). The optimum cut-off value was $1.715 \mathrm{ng} / \mathrm{mL}$ (sensitivity $61 \%$, specificity 22\%) for PAPP-A and 0.905 (sensitivity $51.6 \%$, specificity $39 \%$ ) for PAPP-A MoM. The ideal cut-off value was $25.75 \mathrm{mIU} / \mathrm{mL}$ (sensitivity $56.8 \%$, specificity $30 \%$ ) for $\beta$-hCG and 0.745 (sensitivity $57.9 \%$, specificity $28 \%$ ) for $\beta$-hCG MoM.

Conclusion: PAPP-A and $\beta$-hCG levels were lower in GDM than healthy pregnant women. However, false positive rates for both PAPP-A and $\beta$-hCG are quite high.

Key Words: Gestational diabetes mellitus, Pregnancy-associated plasma protein-A, Chorionic gonadotropin, Beta subunit, Human

ORCID: Gökçen Örgül / 0000-0003-0578-4230, Tan Aylk / 0000-0003-2226-0180, Dilek Şahin / 0000-0001-8567-9048, Aykan Yücel / 0000-0002-5888-692X




\section{GİRIS}

Gebeliğin ilk üç ayında yapılan kombine test başta trizomi 21 olmak üzere diğer kromozom anomalilerin taramasında kullanılmaktadır. Biyobelirteçler ve ultrasonografi arac1lığıyla belirlenen ense saydamlığı (Nuchal translucency; NT) kombine testin bileşenleridir. $\mathrm{Bu}$ amaçla maternal kanda human koriyonik gonadotropin (HCG)'nin serbest beta alt birimi ( $\beta$-hCG ) ve gebelik ile ilişkili plazma protein A (PAPP-A) düzeyleri belirlenerek bazı değişkenlerin de eklenmesi ile kişiye özgü bir risk hesaplanmaktadır (1). Kombine test ile prenatal dönemde Down Sendromu'nu yakalama oranı yaklaşık $\% 90$ olup yanlış pozitiflik oranı $\% 5$ civarındadır (2).

Biyokimyasal belirteçler PAPP-A ve $\beta$-hCG düzeylerinin hem maternal faktörlerden hem de birtakım gebelik değişkenlerinden etkilenebileceği bilinmektedir. Bu sebeple gebelik haftası, fetus sayısı, annenin yaşı, sigara içme durumu, etnik kökeni gibi faktörler göz önüne alınarak sonuç ortancanın katları (multiple of median; MoM) olarak düzeltilmektedir (3). İlk trimester tarama testleri anöploidi saptanmasına olanak sağlamakla birlikte, anormal değerlerin bir takım olumsuz gebelik sonuçları (preterm doğum, preeklampsi, spontan abortus, vb.) ile ilişkili olduğu da gösterilmiştir $(4,5)$.

Gestasyonel diabetes mellitus (GDM) gebelikte ortaya çıan metabolik bir komplikasyon olup bozulmuş glukoz toleransı ile karakterizedir. Coğrafi ve etnik değişkenlere bağlı olarak görülme sıklığı değişmekle birlikte genel olarak prevalansı \%3-7 aralığında değişmektedir (6). Modern hayatta değişen beslenme düzeni ve hareketsizlik gibi nedenlerle GDM sıklığ 1 gün geçtikçe artmaktadır. Maternal, fetal ve neonatal komplikasyonlara yol açan GDM bu açıdan önemli bir halk sağlığı sorunudur (7).

Literatürde GDM ve ilk trimester biyobelirteçlerinin (PAPP-A ve $\beta$-hCG) ilişkisini inceleyen çalışmalar mevcuttur. Çalışmalardan elde edilen sonuçlar ise birbirlerinden farklılık göstermektedir ve çelişkili sonuçlar kafa karışt1rıcıdır (8-10). Özet olarak, GDM tahmininde PAPP-A ve $\beta$-hCG kullanımının faydalı olup olmayacağı konusunda net bir fikir birliği bulunmamaktadır. Bu amaçla üçüncü basamak bir merkez olan hastanemiz verilerini kullanarak Türk gebe kadınlarda gebeliğin ilk üç ayında yapılan kombine test sonuçlarının GDM ile ilişkisini araştırmayı planladik.

\section{GEREÇ ve YÖNTEMLER}

Sağlık Bilimleri Üniversitesi, Etlik Zübeyde Hanım Kadın Hastalıkları Eğitim ve Araştırma Hastanesi'ne başvuran tüm hastalara gebeliğin ilk üç ayında kombine test önerilmektedir. $\mathrm{Bu}$ amaçla ultrasonografi ile baş popo mesafesi (CRL) ölçümünü takiben uygun gebelik haftasında olan fetuslarda (11-14 hafta) NT ölçümü yapılmaktadır. Anneden alınan kandan ise $\beta$-hCG ve PAPP-A bakıldıktan sonra hem sayısal hem de MoM değeri hesaplanmaktadır. Laboratuvarda elde edilen sonuçlara anne yaşı, insülin bağımlı DM öyküsü ve sigara kullanımı ilave edilerek anöploidi taraması gerçekleştirilmektedir.

Hastanemizde takip edilen tüm gebelere GDM taraması yaptırması önerilmektedir. Gebeliğin 24-28. haftaları arasında testi yaptırmayı kabul eden gebelere oral glukoz yükleme testi (OGTT) uygulanmaktadır. Risk faktörleri varlığında (bir önceki gebelikte GDM, birinci derece akrabalarında GDM öyküsü, obezite, makrozomik bebek öyküsü, çoğul gebelik, vb.) ise test ilk trimesterde uygulanmakta gerekirse de ikinci trimesterde tekrarı yapılmaktadır. OGTT için hastanemizde iki basamaklı yaklaşım daha sık tercih edilmektedir. Tarama testi olan $50 \mathrm{gr}$ OGTT sonucu $\geq 140 \mathrm{mg} / \mathrm{dL}$ olan hastalara üç gün uygun diyet verildikten sonra tanı amacıyla 100 gr OGTT yapılmaktadır. Açlık, 1, 2 ve 3. saat serum glukoz düzeyleri için üst sınır sırasıyla $95 \mathrm{mg} / \mathrm{dL}, 180 \mathrm{mg} /$ $\mathrm{dL}, 155 \mathrm{mg} / \mathrm{dL}$ ve $140 \mathrm{mg} / \mathrm{dL}$ kabul edilerek iki veya daha fazla değerinde yükseklik olan hastalara GDM tanısı konulmaktadır. Hastalar bu amaca yönelik hizmet veren Diyabet Polikliniği'nde gebelik takiplerine devam etmektedir.

Çalışma grubunu GDM tanısı alan, ek risk faktörü olmayan ve doğumu 1 Ağustos 2018 ile 31 Ekim 2018 arasında hastanemizde gerçekleşen 95 hasta oluşturmaktadır. Kontrol grubu için Ekim 2018'de hastanemizde termde doğum yapan, ek hastalığı olmayan, gebelik komplikasyonu saptanmayan (preeklampsi, intrauterin gelişim geriliği, plasenta previa, vb.) ve kombine test sonuçlarına ulaşılabilen 100 hasta rastgele seçilmiştir. Yapısal veya kromozomal anomalisi saptanan gebelikler çalışma dışında bırakılmıștır. Anne yaşı, gebelik öyküsü, doğum şekli ve yenidoğan sonuçlarına ait verilere retrospektif olarak bilgisayar sisteminden ulaşılmıştır. Çalışma için Sağlık Bilimleri Üniversitesi Etlik Zübeyde Hanım Kadın Hastalıkları Eğitim ve Araştırma Hastanesi Etik Kurulu tarafından onay alınmıştır (Onay no: 2020/21)

\section{İstatistiksel Analiz}

Elde edilen veriler SPSS (Statistical Package for the Social Sciences) versiyon 22 aracılı̆̆ıyla değerlendirilmiştir. Tanımlayıcı istatistiksel yöntemler için ortalama, standart sapma, ortanca kullanılmıştır. Sürekli değişkenlerdeki dağılım hesaplaması Shapiro-Wilk testi kullanılarak yapılmıştır. İki bağımsız grup arasındaki karşılaştırmalarda normal dağılım şartı sağlanıyor ise Bağımsız Örneklem t testi, sağlanmiyorsa Mann Whitney $U$ testi kullanıldı. Kategorik verilerin karşılaştırılmasında ise Ki-Kare testi kullanıldı. PAPP-A ve $\beta$-hCG düzeylerinin GDM ve kontrol 
grubunu saptama performansını belirlemek açısından bu değişkenler için ROC analizi yapıldı. Bu test ile kesme puanları, duyarlılık ve özgüllük değerleri saptandı ve ROC eğrileri altında kalan alanlar (Area under curve; AUC) kıyaslandı. İstatistiksel olarak anlamlılık düzeyi $\mathrm{p}<0,05$ olarak alındi.

\section{BULGULAR}

Gestasyonel diabetes mellitus grubunda yer alan toplam 95 hastadan 87'si diyet ile regüle (GDM A1) iken kalan 8 hasta $(\% 8,4)$ insülin ile tedavi edilmiştir (GDM A2). GDM tanısı alan hastaların $\mathrm{HbA1C}$ düzeyleri ortalama 5,68 \pm 0,62 idi. Tablo 1 her iki grupta yer alan annelerin demografik verilerini ve bebek sonuçlarını göstermektedir. Doğum kilosu GDM grubunda ortalama $3178 \pm 561$ gr iken kontrol grubunda $3350 \pm 367$ gr olarak saptanmıştır. Doğum haftası ise hasta grubunda $38 \pm 1,58$ hafta iken kontrol grubunda $39 \pm 1,05$ idi. Sezaryen sıklığ GDM hastalarında \%71,6 ve kontrol grubunda $\% 51$ olarak bulunmuştur.

Her iki grupta yer alan hastaların ilk trimester serum $\beta$-hCG ve PAPP-A düzeyleri Tablo 2'de verilmiştir. PAPP-A düzeyi GDM grubunda istatistiksel olarak anlamlı şekilde daha düşük olarak saptanmıştır. PAPP-A MoM düzeyi de GDM grubunda daha düşük olmakla birlikte bu bulgu istatistiksel olarak anlamlı değildir. Serbest $\beta$-hCG açısından ise hem serum düzeyi hem de MoM değerleri GDM grubunda anlamlı olarak düşüktür.
ROC analiz sonuçlarına göre AUC; PAPP-A için 0,397 (95\% CI: 0,318-0,477) ve PAPP-A MoM için 0,428 (95\% CI: $0,347-0,508)$ olarak bulundu ve p değeri sırasıyla 0,013 ve 0,081 idi (Şekil 1). En ideal kesme değeri PAPP-A için $1,715 \mathrm{ng} / \mathrm{mL}$ (duyarlılık \%61 ve özgüllük \%22) ve PAPP-A MoM için 0,905 (duyarlılık \%51,6 ve özgüllük \%39) olarak bulundu.

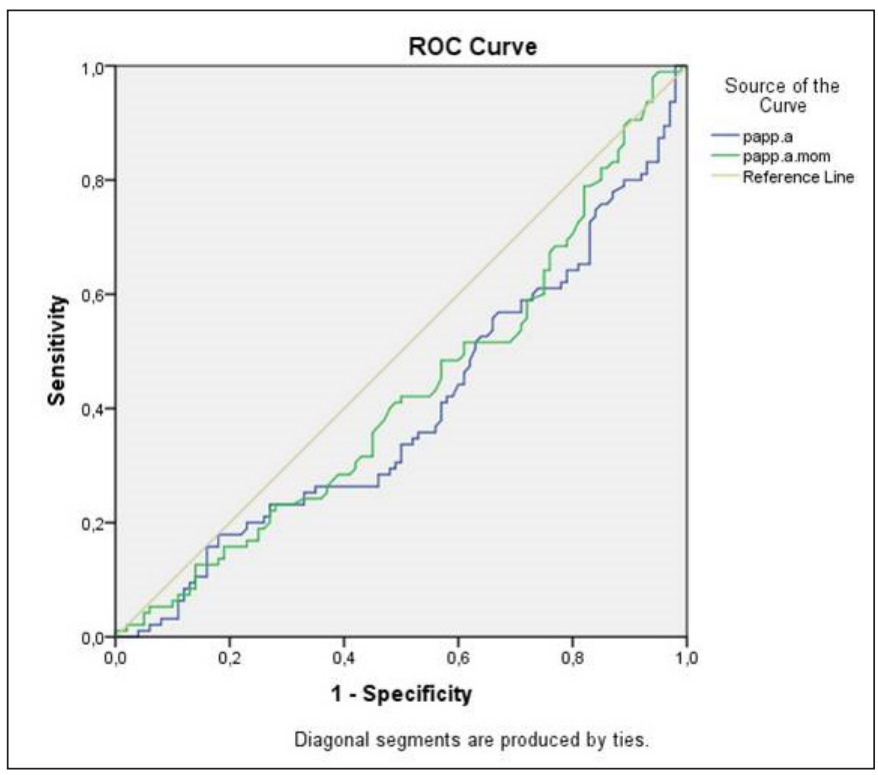

Şekil 1: Gestasyonel diabetes mellitusu olan hastaları saptamada ilk trimester PAPP-A düzeyinin ROC analizi.

Tablo 1: Demografik bulgular ve doğum verileri.

\begin{tabular}{lccc}
\hline & GDM $(\mathbf{n}=\mathbf{9 5})$ & Kontrol $(\mathbf{n}=\mathbf{1 0 0})$ & $\mathbf{p}$ \\
\hline Anne yaşı & $28(20-39)$ & $29(18-40)$ & 0,256 \\
\hline Gravida & $2(1-10)$ & $2(1-5)$ & 0,114 \\
\hline Parite & $1(0-3)$ & $1(0-4)$ & 0,320 \\
\hline Abort & $0(0-9)$ & $0(0-3)$ & 0,313 \\
\hline Yaşayan Çocuk & $1(0-3)$ & $1(0-4)$ & 0,214 \\
\hline Doğum Haftası & $38 \pm 1,58$ & $39 \pm 1,05$ & $<0,05$ \\
\hline Doğum Ağırlı̆̆ (gram) & $3178 \pm 561$ & $3350 \pm 367$ & 0,049 \\
\hline Doğum Şekli & & & 0,001 \\
$\quad$ Sezaryen & $68(\% 71,6)$ & $49(\% 49)$ & \\
$\quad$ Vajinal Doğum & $27(\% 28,4)$ & $51(\% 51)$ & \\
\hline
\end{tabular}

Tablo 2: Kombine test biyobelirteçlerinin karşılaştırılması.

\begin{tabular}{lccc}
\hline & GDM $(\mathbf{n}=\mathbf{9 5})$ & Kontrol $(\mathbf{n}=\mathbf{1 0 0})$ & $\mathbf{p}$ \\
\hline PAPP-A $(\mathrm{ng} / \mathrm{mL})$ & $2,18(0,51-12)$ & $2,89(0,37-15,50)$ & 0,013 \\
\hline PAPP-A MoM & $0,92(0,25-5,83)$ & $1,09(0,23-4,68)$ & 0,081 \\
\hline$\beta$-hCG $(\mathrm{mIU} / \mathrm{mL})$ & $29,4(5,62-116)$ & $37,65(6,8-329,5)$ & 0,001 \\
\hline$\beta$-hCG MoM & $0,86(0,19-3,02)$ & $1,11(0,23-9,08)$ & 0,007 \\
\hline
\end{tabular}


ROC analizi ile elde edilen AUC; $\beta$-hCG için 0,368 (95\% CI: 0,290-0,446) ve $\beta$-hCG MoM için 0,388 (95\% CI: 0,309$0,466)$ olarak bulundu ve p değeri sırasıyla 0,001 ve 0,007 idi (Şekil 2). En ideal kesme değeri B-hcg için $25,75 \mathrm{mIU} / \mathrm{mL}$ ) (duyarlılık \%56,8 ve özgüllük \%30) ve $\beta$-hCG MoM için 0,745 (duyarlılık \%57,9 ve özgüllük \%28) olarak bulundu.

\section{TARTIŞMA}

Çalışmamız sonucunda ilk trimester tarama testinde kullanılan biyokimyasal belirteçler olan PAPP-A ve $\beta$-hCG düzeylerinin GDM gelişenlerde sağlıklı gebelere kıyasla daha düşük seviyelerde olduğu gösterilmiştir. Ancak klinik pratik uygulamada GDM öngörüsünde yol gösterici olarak kullanımının mümkün olmadığı düşünülmüştür. Hem PAPP-A hem de $\beta$-hCG için bulunan kesme değerlerde yalancı pozitiflik oranları oldukça yüksektir.

Modern hayatta değişen beslenme düzeni ve hareketsizlik gibi nedenlerle GDM görülme sıklı̆̆1 gün geçtikçe artmaktadır. Maternal, fetal ve neonatal komplikasyonlara yol açan GDM bu açıdan önemli bir halk sağlığı sorunudur (6). GDM saptanan hastalar uzun dönemde Tip 2 DM gelişimi açısından risk taşımaktadır. GDM ile komplike gebeliklerde preeklampsi, polihidramnios, erken doğum, sezaryen/operatif doğum ve pyelonefrit gibi birçok obstetrik komplikasyon daha sıktır. Ayrıca GDM'li anne bebeklerinde makrozomi görülme sıklığı ve buna bağlı doğum travması, brakiyal pleksus hasarı gibi neonatal morbidite ve mortalite riski de artmaktadır (7).

Plasenta tarafından üretilen PAPP-A ve $\beta$-hCG hormonları glikoprotein yapıda olup gebelikte maternal kanda saptanabilmektedir. PAPP-A'nın temel fonksiyonu insülin benzeri büyüme hormonunun (insüline like growth factor; IGF) biyoyararlanımını artırarak plasentaya glukoz ve aminoasit transportuna aracılık etmektir. Çinko bağımlı bir metalloproteinaz olan PAPP-A dokuda matriksin yeniden yapılandırılmasında ve damar duvar bütünlüğünün korunmasında etkilidir (11). Gebelik hormonu olarak da isimlendirilen hCG üreme fizyolojisinde önemli role sahiptir. Gebeliğin oluşması ve devamı, plasentasyon ve embryo büyümesindeki çeşitli basamaklarda görev yapmaktadır (12). Fizyolojik fonksiyonlarının yanı sıra bu iki hormon kromozom anomalilerin taranması amaciyla da uzun süredir kullanılmaktadır. Günümüzde birçok ülkede kombine test tüm gebelere uygulanmaktadır. Sağlık Bakanlığı tarafından da önerilen bu test ülkemizde günlük pratikte yerini almıştır (13).

Dugoff ve ark. ilk trimester PAPP-A düzeylerinin gebelik komplikasyonları ile ilişkisi olduğunu göstermişlerdir. Düşük PAPP-A saptanan gebeliklerde $(<5$ persentil) düşük doğum ağırlığı, preeklampsi, gestasyonel hipertansiyon,

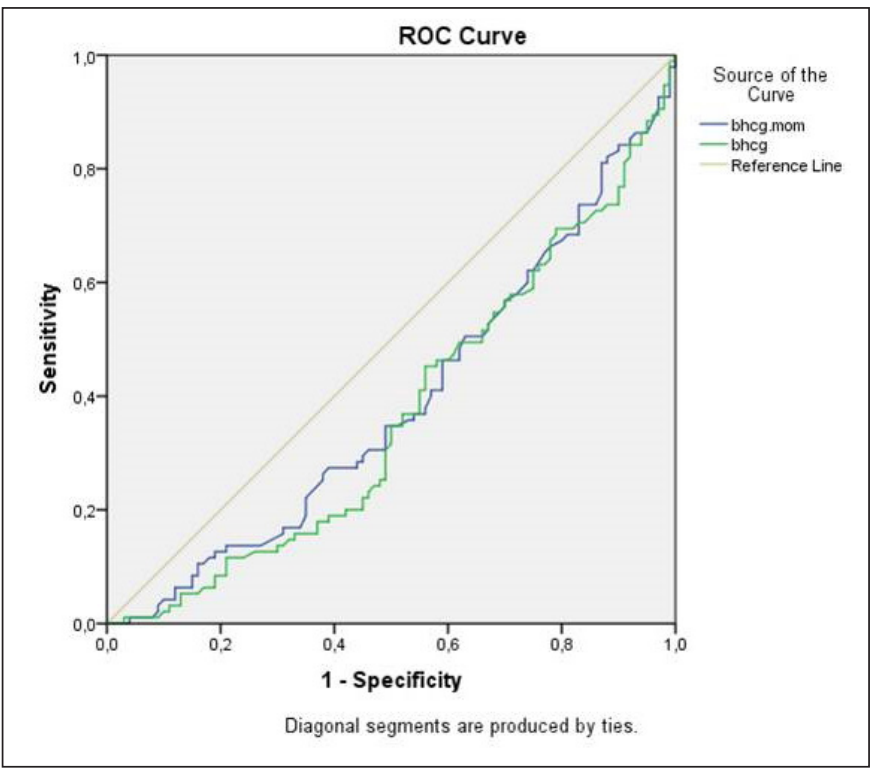

Şekil 2. Gestasyonel diabetes mellitusu olan hastaları saptamada ilk trimester b-hCG düzeyinin ROC analizi.

preterm doğum, ölü doğum ve dekolman plasenta sıklığ1nın arttığ́ gösterilmiştir (8). Düşük PAPP-A düzeyinin IGF bağlayıcı protein düzeylerini artırdığı ve buna bağlı serum serbest IGF seviyesinde azalmaya yol açtı̆̆ bilinmektedir. Fetal büyümenin düzenlenmesinde rol alan IGF düzeylerindeki azalmanın olumsuz gebelik sonuçları ile ilişkisi olduğu düşünülmektedir (14). İlk trimester PAPP-A düzeylerinin diyabet ile komplike gebeliklerde farklılık gösterip göstermediği 2012 yllında yapılan bir çalışmada araştırılmıştır. Geniş bir kontrol grubu ile DM saptanan gebelikler (tip 1, tip 2, GDM) karşılaştırıldığında yalnızca tip 2 DM'de PAPP-A seviyelerinin bir miktar düştügü gösterilmiştir (4). Yalnızca GDM ile sağlıklı gebeliklerin ele alındığı bir başka çalışmada ise PAPP-A düzeylerinin \%7-9 daha düşük olduğu belirlenmiştir (15). Bununla birlikte, GDM ve insülin bağımlı DM gebeliklerinde ilk trimester PAPP-A düzeylerinin anlamlı fark göstermediğini bildiren çalışmalar da mevcuttur $(9,10)$. Biz de çalışmamızda literatüre benzer olarak gebeliğin ilk üç ayındaki PAPP-A düzeylerinin GDM gelişen Türk kadınlarda daha düşük olduğunu saptadık.

İlk trimester düşük $\beta$-hCG düzeylerinin spontan gebelik kaybı ile ilişkili olduğu ancak preterm eylem, büyüme kısıtlılığı, oligohidramnioz ve preeklampsi ile arasında bir ilişki olmadığ gösterilmiştir (5). Savvidou ve ark. gebeliğin ilk üç ayındaki $\beta$-hCG düzeylerinin diyabet ile komplike gebeliklerde sağlıklı gebeler ile benzer değerde olduğunu bildirmişlerdir (4). Buna karşın, 9 çalışmanın sonuçlarının dahil edildiği 2018 yılında yapılan bir meta-analizde düşük $\beta$-hCG ile GDM ortaya çıkması arasında bir ilişki olduğu gösterilmiştir (3). Ayrıca, 10 persentil altındaki $\beta$-hCG 
düzeylerinin GDM gelişen gebelerin \%20'sinde saptanabildiği gösterilmiştir (16). Çalışmamızdan elde edilen sonuçlara göre GDM ortaya çıan kadınlardaki ilk trimester $\beta$-hCG düzeyleri sağlıklı gebelere kıyasla daha düşüktür.

\section{Çalışmanın Kısıtlılıkları}

Çalışmamızda bir takım kısıtlılıklar söz konusudur. İlk olarak hasta sayısı kısıtlıdır ve istatistiksel farkı göstermede bu sayı yetersiz kalabilir. İkincisi verilere ulaşabilmek için dosyalar geriye dönük olarak taranmıştır. Ayrıca, çalışma grubunu tek bir merkeze başvuran olgular oluşturmaktadır ve farklı coğrafi bölgelerdeki merkezlerin de katılımı ile tüm ülkeyi yansıtacak çalışmalar planlanmalıdır. Son olarak, GDM için risk faktörü olan gebelik öncesi vücut kütle indeksi, gebelikte kilo alımı ve önceki gebelikte GDM öyküsü gibi faktörler çalışmada yer almamaktadır.

\section{SONUÇ}

$\mathrm{Bu}$ çalışma ile ilk trimester PAPP-A ve $\beta$-hCG düzeylerinin GDM ortaya çıkan gebeliklerde daha düşük olduğu gösterilmiştir. En ideal kesme değeri PAPP-A için 1,715 ng/ $\mathrm{mL}$ (duyarlılık \%61 ve özgüllük \%22) ve PAPP-A MoM için 0,905 (duyarlılık \%51,6 ve özgüllük \%39) iken $\beta$-hCG için $25,75 \mathrm{mIU} / \mathrm{mL}$ (duyarlılık \%56,8 ve özgüllük \%30) ve $\beta$-hCG MoM için 0,745 (duyarlılık \%57,9 ve özgüllük \%28) olarak bulunmuştur. Ancak bu değerlerde yanlış pozitiflik oldukça yüksek olup tek başlarına tarama testi olarak kullanımı sakıncalıdır. Tüm gebelere uygun gebelik haftasında OGTT ile GDM taraması yaptırması önerilmelidir.

\section{Çıkar Çatışması}

Yazarlar arasında herhangi bir çıkar çatışması yoktur.

\section{Finansal Destek}

Çalışma için finansal destek sağlayan kurum ya da kuruluş yoktur.

Yazarların Makaleye Katkı Beyanı

Verilerin analizi, makale yazımı, literatür tarama: Gökçen Örgül, Veri toplanması: Tan Ayık, Makale yazımı: Dilek Şahin, Makale yazımı: Aykan Yücel.

\section{KAYNAKLAR}

1. Wald NJ, Hackshaw AK. Combining ultrasound and biochemistry in first-trimester screening for Down's syndrome. Prenat Diagn. 1997;17(9):821-829.

2. Ökem ZG, ve ark. Economic analysis of prenatal screening strategies for Down syndrome in singleton pregnancies in Turkey. Eur J Obstet Gynecol Reprod Biol. 2017;219:40-44.
3. Donovan BM, ve ark. First trimester prenatal screening biomarkers and gestational diabetes mellitus: A systematic review and meta-analysis. PloS one. 2018;13(7):e0201319.

4. Savvidou $M$, ve ark. First trimester maternal serum free $\beta$ human chorionic gonadotropin and pregnancy-associated plasma protein $\mathrm{A}$ in pregnancies complicated by diabetes mellitus. BJOG. 2012;119(4):410-416.

5. Yaron Y, ve ark. First trimester maternal serum free human chorionic gonadotropin as a predictor of adverse pregnancy outcome. Fetal Diagn Ther. 2002;17(6):352-356.

6. Ferrara A. Increasing prevalence of gestational diabetes mellitus: A public health perspective. Diabetes Care. 2007;30(Supplement 2):141-146.

7. Ayhan S, ve ark. Prognosis of pregnancies with different degrees of glucose intolerance. Gynecology Obstetrics \& Reproductive Medicine. 2016;19(2).

8. Dugoff L, ve ark. First-trimester maternal serum PAPP-A and free-beta subunit human chorionic gonadotropin concentrations and nuchal translucency are associated with obstetric complications: A population-based screening study (the FASTER Trial). Am J Obstet Gynecol. 2004;191(4):14461451.

9. Husslein $\mathrm{H}$, ve ark. Association between pregnancy-associated plasma protein-A and gestational diabetes requiring insulin treatment at 11-14 weeks of gestation. J Matern Fetal Neonatal Med. 2012;25(11):2230-2233.

10. Tul N, ve ark. Predicting complications of pregnancy with first-trimester maternal serum free- $\beta$ hCG, PAPP-A and inhibin-A. Prenat Diagn. 2003;23(12):990-996.

11. Shiefa $S$, ve ark. First trimester maternal serum screening using biochemical markers PAPP-A and free $\beta$-hCG for down syndrome, patau syndrome and edward syndrome. Indian J Clin Biochem. 2013;28(1):3-12.

12. Theofanakis $\mathrm{C}$, ve ark. Human chorionic gonadotropin: The pregnancy hormone and more. Int J Mol Sci. 2017;18(5):1059.

13. TC Sağlık Bakanlığı, Turkish Public Health Instutition, Department of Women's Reproductive Health). Doğum Öncesi Bakım Yönetim Rehberi (Antenatal Care Management Guideline), Ankara, 2014.

14. Irwin J, ve ark. Role of the IGF system in trophoblast invasion and pre-eclampsia. Hum Reprod. 1999;14(suppl 2):90-98.

15. Spencer K, Cowans NJ. The association between gestational diabetes mellitus and first trimester aneuploidy screening markers. Ann Clin Biochem. 2013;50(6):603-610.

16. Ong CY, ve ark. First trimester maternal serum free $\beta$ human chorionic gonadotrophin and pregnancy associated plasma protein A as predictors of pregnancy complications. BJOG. 2000;107(10):1265-1270. 